\title{
THE BEHAVIOURAL DIMENSION OF SME'S OWNER ON AFFECTING THE FINANCIAL DECISIONS
}

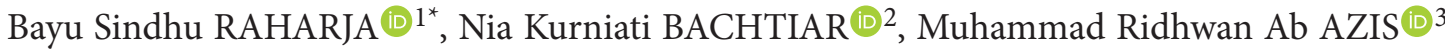 \\ ${ }^{1}$ Department of Management Zakat and Waqf, Faculty of Sharia, \\ Universitas Islam Negeri Raden Mas Said Surakarta, Sukoharjo, Indonesia \\ ${ }^{2}$ Department of Management, Faculty of Economics and Business, \\ Universitas Muhammadiyah Magelang, Magelang, Indonesia \\ ${ }^{3}$ Faculty of Economics and Muamalat, Universiti Sains Islam Malaysia (USIM), Kuala Lumpur, Malaysia
}

Received 7 September 2020; accepted 2 November 2021

\begin{abstract}
This research seeks the effect of behavioural and non-behavioural factors of SME's owners and their business characteristic on the financing decisions. Moreover, this research categorized SMEs owners based on their behavioural aspects on establishing a behavioural mapping in SMEs industry. The sample of this research is the informal SMEs owners in Surakarta, Central Java, Indonesia. In investigating the relationship of the independent variable on financial decision making, this research employed the hierarchical linear multiple regression model (HLMR) and multiple logistic regression (LR). Furthermore, this research employed cluster analysis for building a behavioural mapping in SMEs industry. This study discovered a significant effect of behavioural aspects of SME's owners on the financing decisions, which is, instead of having significant enforcement on the financing decisions, the non-behavioural aspects were more likely impacted on the SMEs owners' investment decisions. The finding shows that there are three significant groups of SMEs owners in the Surakarta region. The result of this research gives key insights, mainly to the involved stakeholder to keep the sustainability of the SMEs industry.
\end{abstract}

Keywords: capital structure, financial behavior, financial education, financing development, investment decisions.

JEL Classification: D11, G20, G21, G41, G51.

\section{Introduction}

Hitherto, the issues of financial decisions alleviate attractively as well deserve significant attention from many scholars, beside the dominant issue concerning inconsistencies result from classical theory of financial decisions. The debates on the dexterity of the classical theory on spelling out financial decisions in SMEs industry are intriguing to discuss. For instance, one of the many classical theories in the financial decision is the pecking order proposed by Myers and Majluf (1984). This advised the hierarchical source of capital that should be embraced by the financial manager to diminish firms' risk and exaggerate corporate financial performance through excellent capital structure. The theory always presumed that financial managers behave rationally in dealing with the information around themselves, so they usually deflect higher-risk on financing policy. However, Gupta and Gregoriou (2018) divulged that SMEs have a distinct characteristic than settled large corporations. SMEs have more extraordinary level of information asymmetry than other industry. Thus, it should wield a distinctive approach to seek how SMEs owners decide their financial decisions.

Waharini et al. (2018) recognized that the appearing of high-level information asymmetry in SMEs industry due to financial reporting that not arranged routinely and systematically. There was no perceptible reference which could assisst SMEs owners in making appropriate financial decisions. As a result, it induced them to be reactive and trapped in bias decisions making. Moreover, financial institutions (FIs), as a provider of funds, also affected by these conditions. They tend to be cautious in allocating their funds to SMEs. Referred to the data from Bank of Indonesia that signed the reason FIs should be cautious, one of which is due to the non-performing loans in microbusiness thrived at 2.5\% from 2013 to 2017 .

As the higher level of asymmetry information, FIs are hesitant to carry higher risk of credit default that

${ }^{*}$ Corresponding author. E-mail: bayusindhu@iain-surakarta.ac.id 
appointed in SMEs industry. Therefore, the amount of funds to the micro-business enterprises was not assigned optimally. In 2013 to 2017, Bank of Indonesia released the evidence of the declining credit allocation for the micro-business sector in Indonesia. Beside of that, Kon and Storey (2003) proposed the other unique characteristic of SMEs industry. They asserted that SME's owners turn to be fear and not confident in handling the amount of funds from FIs. So even though financial institutions strive to raise the supply of funds to micro-business sector, the SME's owners will not necessarily grab the funds all at once. This caused more complicated cases, mainly, in how to preserve the sustainability of the SME industry by passing through many useful financial products. Therefore, we call for a comprehensive research that inquiry SME's owners to resolve their financial decisions. By having such depth recognition of financial decisions in SMEs industry, it will grant many advantages to all of involved stakeholders. For instance, FIs can push optimal supply of funds in SME industry effectively; the government as a macropolicymaker establishes appropriate policy on keeping this sector flourishing as well.

The previous research deliberated financial decisions making in SMEs industry far focus entirely on the demand side of the market. There are too many researches focus on the supply side, which concerning of how FIs avert the likeliness of higher credit default (Chijoriga, 2011; Alali \& Romero, 2013; Osei-Assibey \& Asenso, 2015; Vithessonthi, 2016). Although it is hampered, there are some researches could be contrived as a reference, for instance, Rao et al. (2019) which conducted an attention of several factors that encouraged SMEs owners in financing decisions. The study delivered that financial performance indicators have a significant enforcement on unfolding of decisive and appointing financial sources. Baker et al. (2020) observed characteristics of SMEs, such as firms' characteristics and owner's characteristics, significantly concerned to the decisions of selecting financing sources. Two earlier studies with regard to SMEs owners in financing decisions represent the picture of previous studies on this topic, which divided into 2 (two) approaches. First, SMEs financing decisions based on an indicator of financial performance approaches (Cassar \& Holmes, 2003; García-Teruel \& Martínez-Solano, 2010; Iturralde et al., 2010; Ferrando et al., 2017; Botta, 2019; Maes et al., 2019; Nizaeva \& Coskun, 2019). Second, the decision of financing decisions based on the firms' characteristics (attribute) and the behaviour of the owners (Dong \& Men, 2014; Rao \& Kumar, 2018; Galli et al., 2019; Baker et al., 2020).

The object of this research is informal SMEs owners in Surakarta, Central Java, Indonesia. McCarthy et al. (2017) illustrated the urgency of a particular and distinguishing approach to inquiry a piece of soft information in SMEs industry. Therefore, this investigation employed a behavioural approach to delve into financial decisions of SMEs' owners. Consider to Arya et al. (2013), it its more appropriate to dig into non-explicit side of business actors in
SMEs industry. As a proxy of behavioural approach, this research preceded risk-seeking, growth-seeking, profitseeking, and ownership-orientation of SMEs owners. All of these behaviours were alleged from Rao and Kumar (2018), therein both conceptual definition and measurement scales.

However, this research undertook to assign the gap in this area, which are forgotten by previous scholars. Based on the literature study, much of the previous research excluded several essential factors such as dimensions of knowledge possessed by SMEs owners. Awaluddin (2015) asserted that the critical and ultimate problem of SMEs industry in Indonesia is insufficient knowledge, therein regarding the knowledge of financing and investment decisions. These cases collide on the limited access of SMEs owners in attaining more assisstence from financial products. This research introduced financial literacy and educational level as a proxy to assess the knowledge of SMEs owners. Thus, it introduced further to a non-behavioural approach to investigate financial decisions of SMEs owners. Moreover, this inquiry seeks the behavioural mapping of SME's owner by clustering the group of samples based on their behaviour as well. It is deeply compelling in showing the detail characteristic of SMEs in Indonesia.

The arrangement of this research paper is divided into sixth parts. First, it discusses the background of the research conducted, as well some problems arise in financial decisions dynamics on SMEs sector. In the second part, this paper presents a literature review of several previous studies relates to the identified factors of both financing decisions and investment decisions. Then, in the third part, it explains the method of this research. The fourth and fifth sections, it elaborates and concludes the research results. While in the sixth part, this paper will discuss the implications of the results and the possibilities that will be carried out in future research.

\section{Literature review}

\subsection{SMEs specific/characteristic factor}

It is widely accepted that previous studies discovered firms' characteristic, such as firm size as well as firm age significantly affect both financing decision and investment decision. Following section explains the logical reason of how these factors have a remarkable part in SMEs owners' financial decisions.

\subsection{Firm age and firm size}

All this time, literature on how SMEs characteristics influenced financing and investment decisions have not explored enough. Alternatively researches are focus more to enterprises, Situm (2014) employed his research at several multinational corporations in Austria, as a result, firm age (older or younger) and firm size (greater or less) are significant factors as predictors of corporate bankruptcy, it was discovered that the older (greater) the firms, less 
likely to face bankruptcy. The logic behind this related to accessibility of capital - the older (greater) firms, the more trusted and more convenient to access the source of capital than the younger (less) firms. Consequently, bankruptcy that occurred by liquidity risk is less for them. So are in the case of investment decisions, Ghafoorifard et al. (2014) proved that the older (greater) firms are also more accessible to many investment products, whereby older (greater) firms got superb advantage to rise their corporate financial performance. It confirmed by many previous researches that also found the significant relation of firms age and firms size on the corporate financial performance (Ling et al., 2007; Loderer \& Waelchli, 2011; LiPuma et al., 2013; Arend, 2014; Raharja, 2012, 2014; Raharja \& Mranani, 2019).

Although earlier explanation emphazised the case of large enterprises, however, these premises also applicable to SMEs industry. The older (greater) SMEs tend to have higher access to many financial products, such as credit funds and investment products than the younger (less) SMEs. Therefore, this research proposes a hypothesis that older (greater) SMEs have higher probability to use debt for financing decisions than younger (less) SMEs. So are in the case of investment decisions, the older (greater) SMEs tend to have higher probability to invest than the another one.

\subsection{SMEs' owners atttribute}

This study divides SMEs attribute into 2 (two) types, they are behavioural and non-behavioural. As mentioned previously, behavioural attributes employed in this study are growth-seeking, profit-seeking, control ownership, and risk-seeking. In contrast, non-behavioural attributes included financial literacy, gender, and the level of education of business owners. The following section explains the literature review and constructs such logical reasons on how the SMEs owners' attributes affected financial decisions.

\subsection{Behavioral attribute of SMEs owner}

The behavioural attributes of SMEs owners are essential factors in explaining how they had made their financial decisions. For instance, Arya et al. (2013) stated that behavioural dimension largely determines the debtor's decision for taking a debt. Likewise, Eckel et al. (2007) also had found that behaviour of low-risk tolerance would encourage someone for taking a debt regularly. Then, Rao and Kumar (2018) proved that behavioural attributes of SMEs owners were the greatest determinants in financial decisions among all. In those studies, behaviours that influenced financial decisions were growth-seeking, riskseeking, profit-seeking, and ownership-orientation. As for an explanation of those behaviours as follows: growth-seeking is a behaviour that always oriented to business growth, therefore, growth-seeking SMEs owners dominantly dares to use debt in pursuing their business growth. Raharja et al. (2017) proved that orientation on business growth is positively related to amount of debt used as a source of capital. Likely, Ramezani et al. (2002) also elaborated that growing firms need such considerable debt to improve their business operationalization effectively. Therefore, this study argues that SMEs owners whose higher growthseeking behaviour will have higher debt than SMEs owners who have not growth-seeking oriented. In a while, instead of has a similar effect, growth-seeking hurts the investment decision. Indeed, growth-seeking SMEs owners are reluctant to save their funds; they used those funds to habilitate and maximize their business growth. Thus, this research hypothesized that SMEs owners whose higher growth-seeking behaviour tend to have a lower probability of investing than another.

Following to that, risk-seeking is a behaviour that shows the courage of SMEs owner in taking risks for their business operation, hence risk taking is included in financial decision. Many scholars believed that debt was categorized to high-risk financial instrument due to a lot of financial expenses occurred. Thus, there was relationship indications between debt and risk-seeking behaviour. Karpavičius and Yu (2019) underlined that person with a low-risk tolerance profile (high-risk seeker) would have a high tendency to take on debt. Arya et al. (2013) and Raharja et al. (2017) also declared that financial manager whose higher risk-seeking behaviour tend to have a higher probability of taking higher debt for financing their firms. Therefore, this research hypothesized that risk-seeking behaviour positively relates to the propensity to use debt as a source of financing decisions. Furthermore, this research proposed the hypothesize that risk-seeking behaviour harm investment decisions due to SMEs owners whose less risk-seeking behaviour is reluctant to save their funds. Instead of saving their funds, they would maximize the availability of funds to reach higher profitability as possible.

Profit-seeking behaviour is a behaviour that showed a more considerable effort to reach profit maximization. In business ethics area, this behaviour is usually confronted with the virtuous (Netle \& Munger, 2016). Many people recognize that profit-seeking behaviour is identically as a bad behaviour due to creating hyper-exploitation for reaching higher profitability. This research disagrees with that opinions, instead of being assessed separately, profitseeking behaviour and virtuous should be judged as inseparable entities. Business unit is an organization which operated as an economic function for generating a profit. On the other side, business unit also ought to undertake as a social function which contributes to environmental sustainability. Both of those functions, economic and social, should work together. However, in reality, some business owners trapp to do separately. Some of them did not perform both functions simultaneously. As a result, this seems attested the stereotypes that assumed profit-seeking behaviour is contrary to virtuous. Therefore, SMEs owners whose higher risk-seeking behaviour tend to give more attention to the way of reaching superb financial 
performance and being more competitive than another. Otherwise, SMEs owners whose less profit-seeking behaviour preferred to act as safe as possible. Such running the business in an effortless spirit, implementing poor strategy, reluctant for embracing new challenge, etc.

Tambunan (2009) confirmed some SMEs owners in Indonesia gave up and only believed in their own cash for developing their business. They disinclined to utilize external financing for undertaking their business. Instead of persuing optimal gain, their effort concerned overly in a way to overtaken the break-even point. In case of the break-even point accomplished, they felt quickly satisfied. These behaviour caused them to be less competitive. It was not surprising when Setyawan Agus et al. (2015) found out competitiveness is one of the main critical problem of SMEs in Indonesia. This is different compare to SMEs owners who used debt as source of capital. Wherefore the debt repayments continued to grow, they always ougth to to ensure the profit of firms also accrue in the future. Therefore, this research hypothesized that profit-seeking behaviour has positive relation to probability of SMEs owners to take some debt. In contrast to the financing decision, profit-seeking behavior has negative relation to probability of SMEs owners to save their money in FIs as an investment. Rather than saving their funds, SMEs owners who have higher profit-seeking behaviour tend to spend their funds as a working capital.

Ownership-orientation behaviour is a behaviour that always oriented to maintain their business ownership. SMEs owners who have higher ownership-orientation behaviour tend to be curious to maintain and hold their business. They reluctant to overtake some opportunities which might harmed their business in the future. The real example of this behavior can be easily found ini familyowned business. Mulyani et al. (2016) confirmed that in order to avoid bankruptcy, family-owned business evade debt as such riskier source of capital. In that kind of business, failure means threatening their ownership. Remember that debtholder is preferred person whose rights must be fullfilled when firms encounter a bankruptcy (Shleifer \& Vishny, 1986). Therefore, this research proposed SMEs owners whose high ownership-orientation behaviour tend less likely use debt as a source of capital for their business. Instead of taking out debt, they prefer internal funds for financing their business.

\subsection{Non-behavioral attributes of SMEs owner}

As mentioned in the previous part, this research proposed the non-behavioural aspects as a determinant of financing and investment decisions in SMEs industry. As for the non-behavioural aspects of SMEs owners are gender, educational level, and financial literacy. In which, the last two variables represented a proxy of SMEs owners' knowledge.

Financial literacy is a variable that measure individual level of sensitivity analysis to the kind of financial issue such as financial product, and financial problemsolving. Previous studies found that financial literacy as a significant factor which affect financial decision behavior (Rooij et al., 2011; Jappelli \& Padula, 2013; Aren \& Zengin, 2016; Mouna \& Anis, 2017; Zhang et al., 2020; Fujiki, 2020; Jiang et al., 2020). Moreover, Grohmann (2018) discovered the breakthrough reason behind the higher income achieved by middle-upper societies. His research showed that the middle-upper had a higher level of financial literacy than bottom class; thus, it played such a significant role in determining their higher financial wealth. The higher level of financial literacy control their behaviour in spending and consuming money. It also affect their investment behaviour, thereby, they actively invest to guarantee their money always grow in the future.

In contrast, bottom society who have lower level of financial literacy are always vulnerable to irrational financial decisions making since there is not enough knowledge for controlling their behaviour. They have difficulty in controlling excessive consumption (Zhang et al., 2020) and preparing future risks through investment decisions. As a result, there is no investment benefit of financial product to bottom class, and finally, they would have less financial wealth than middle-upper societies. In tune to Jappelli and Padula (2013) that confirmed the hypothesis of positive relationship between financial literacy and investment decisions. Zhang et al. (2020) argued, that instead of consuming more debt, people who had higher financial literacy tend to give more attention to save their money in investment products such saving deposits in FIs. Lusardi et al. (2019) precisely found in his experimental research that if financial literacy goes up by one unit, the level of investment deposits would be rise at $10 \%$. Therefore, this research proposed that financial literacy has a negative relation to the SMEs owners' debt consumption, whereas in investment decisions, this research proposed otherwise. Consider to Fujiki (2020), people whose higher level of financial literacy tend to have less cash demand as well a high level of cash holding. Thus, SMEs owners whose higher level of financial literacy most likely save their money in the form of FI's deposits.

The similar exegesis also prevail to variable of SMEs owners' education level. Sun et al. (2020) had stated that well-educated economic actor would understand better to information around him, then it would have an impact on keeping any decisions taken from such irrational behavioural biases. And indeed, it is not surprising when Bannier and Schwarz (2018) found an interesting evidence that SMEs owners' education level will affect the financial welfare the have. A higher level of education would cause SMEs owners to be more careful in spending money to meet their needs. They would be subtle in this regard, particularly, their consumptions on high-risk financial instruments such using debt for financing decisions (Zhang et al., 2020). Furthermore, they would prefer to spend their money on financial instruments which could indemnify the growth of funds in the future, such as saving deposits in FIs. Thus, this study presumed that the higher level of education is positively related to the decision of saving money in the form of deposits. Apart of the relation 
on investment decisions, the level of education presumed to be negavitely related to the probability of using debt for financial decisions.

\section{Research method}

This study employed quantitative survey method on 592 SME's owners in municipality of Surakarta, Central Java, Indonesia. Such strategic data collecting is choosen to cathup from perceptional side, besides of that, it further applied observation instruments to collect data on the level of financial literacy in each sample. As mentioned before, the sample of this research is SME owners in informal sector, mainly those scattered in several well-known traditional markets in municipality of Surakarta. Furthermore, as for measuring behavioral aspects, such as riskseeking, growth-seeking, profit-seeking, and ownership orientation, this study referred to Rao et al. (2019). Table 1 presents the following measurements of behavioral aspects, which are assessed by the perception of business owner on several types of statements.

Table 1. The behavioral aspect measurement of SME's owner (source: developed in the current study)

\begin{tabular}{|l|l|}
\hline $\begin{array}{l}\text { The main goal of a business is to } \\
\text { increase and expand market share } \\
\text { (opening new branches) as quickly } \\
\text { as possible }\end{array}$ & Growth-seeker \\
\hline $\begin{array}{l}\text { The main goal of my business is to } \\
\text { get the maximum profit }\end{array}$ & Profit-seeker \\
\hline $\begin{array}{l}\text { I will maintain my business } \\
\text { ownership with all my strength (Will } \\
\text { not share business ownership) }\end{array}$ & Ownership-orientation \\
\hline $\begin{array}{l}\text { I dare to take as much risk as } \\
\text { possible to accelerate the growth rate } \\
\text { of my business }\end{array}$ & Risk-seeker \\
\hline
\end{tabular}

Meanwhile, to measure the level of financial literacy, this research employed observation techniques through survey instruments which formulated by Organisation for Economic Co-operation and Development (OECD). Table 2 showed the following of all the measurement variables used in this study.

Meanwhile, to analyze the data, this study employed 2 (two) analytical tools approaches, namely hierarchical multiple linear regression (HMLR) and logistic regression (LR). The analysis model is as follows:

\section{- Model a:}

$E X T R L_{-} F D_{i}=G R O W T H \_S_{i}+P R O F I T \_S_{i}+R I S K_{-} S_{i}-$ $F L_{i}+F_{\text {IRM }} M_{\text {Agei }}+F I R M_{\text {Sizei }}+E D U_{\text {Leveli }}+G E N D E R_{i, t}+e_{i}$;

- Model b:

$T O T \_E X T R L_{i}=G R O W T H \_S_{i}+P R O F I T \_S_{i}+R I S K_{-} S_{i}-$ $F L_{i}+F I R M_{\text {Agei }}+$ FIRM $_{\text {Sizei }}+E D U_{\text {Leveli }}+$ GENDER $_{i, t}+e_{i}$

\section{- Model c:}

$I N V S_{-} F D_{i}=G R O W T H \_S_{i}+P R O F I T \_S_{i}+R I S K_{-} S_{i}-$ $F L_{i}+$ FIRM $_{\text {Agei }}+$ FIRM $_{\text {Sizei }}+E D U_{\text {Leveli }}+G E N D E R_{i, t}+e_{i}$;
Table 2. The measurement variable (source: developed in the current study)

\begin{tabular}{|c|c|c|}
\hline & Variable & Measurement \\
\hline 1. & $\begin{array}{l}\text { Growth- } \\
\text { seeker }\end{array}$ & $\begin{array}{l}\text { Developed from Rao et al. (2019) in } \\
\text { Table } 1\end{array}$ \\
\hline 2. & $\begin{array}{l}\text { Profit- } \\
\text { seeker }\end{array}$ & $\begin{array}{l}\text { Developed from Rao et al. (2019) in } \\
\text { Table } 1\end{array}$ \\
\hline 3. & Risk-seeker & $\begin{array}{l}\text { Developed from Rao et al. (2019) in } \\
\text { Table } 1\end{array}$ \\
\hline 4. & $\begin{array}{l}\text { Ownership } \\
\text { orientation }\end{array}$ & $\begin{array}{l}\text { Developed from Rao et al. (2019) in } \\
\text { Table } 1\end{array}$ \\
\hline 5. & $\begin{array}{l}\text { Financial } \\
\text { literacy }\end{array}$ & $\begin{array}{l}\text { The measurement from OECD's financial } \\
\text { literacy }\end{array}$ \\
\hline 6. & Firm age & $\begin{array}{l}\text { Calculated from the firm's first time } \\
\text { establishement until the time of the } \\
\text { observasion of this research } \\
\text { firmage = the year of researchobservation- } \\
\text { thetimeoffirms 'establishement }\end{array}$ \\
\hline 7. & Firm size & $\begin{array}{l}\text { Calculated from the total amount of sales } \\
\text { per day }\end{array}$ \\
\hline 8. & $\left(\mathrm{EDU}_{\text {Level }}\right)$ & $\begin{array}{l}\text { The education level of SME's owners. If } \\
\text { they graduated from: } \\
\text { Elementary school }=1 \\
\text { Junior high school = } \\
\text { Senior high school = } 3 \\
\text { Bachelor degreee }=4 \\
\text { Master degree }=5 \\
\text { Doctor degree }=6\end{array}$ \\
\hline 9. & Gender & $\begin{array}{l}\text { If the gender of SME's owners are, } \\
\text { Male }=1 \\
\text { Female }=0\end{array}$ \\
\hline 10. & EXTRL_FD & $\begin{array}{l}\text { The decision to choose debt in financial } \\
\text { institutions as sources of capital. If, } \\
\text { The SME's owners have debt, the score } \\
\text { is } 1 \\
\text { If the SME's owners do not have debt, the } \\
\text { score is } 0\end{array}$ \\
\hline 11. & $\begin{array}{l}\text { TOT } \\
\text { EXTRL }\end{array}$ & $\begin{array}{l}\text { The amount of debt held by the SME's } \\
\text { owners, calculated by the questions. If } \\
\text { they have, } \\
\text { < IDR } 20,000,000 \text { the score is } 1 \\
\text { Between IDR } 20,000,000 \text { to IDR } \\
49,000,000 \text { the score is } 2 \\
\text { Between IDR } 50,000,000 \text { to IDR } \\
100,000,000 \text { the score is } 3 \\
>\text { IDR } 100,000,000 \text { the score is } 4 \\
\end{array}$ \\
\hline 12. & INVS_FD & $\begin{array}{l}\text { The amount of saving deposit in financial } \\
\text { institutions that held by SME's owners. If, } \\
\text { The SME's owners have of saving deposit } \\
\text { the score is } 1 \\
\text { If SME's owners do not have a saving } \\
\text { deposit the score is } 0\end{array}$ \\
\hline 13. & TOT_INVS & $\begin{array}{l}\text { The amount of saving deposit held by the } \\
\text { SME's owners, calculated by the questions. } \\
\text { If they have, } \\
<\text { IDR } 20,000,000 \text { the score is } 1 \\
\text { Between IDR } 20,000,000 \text { to IDR } \\
49,000,000 \text { the score is } 2 \\
\text { Between IDR } 50,000,000 \text { to IDR } \\
100,000,000 \text { the score is } 3\end{array}$ \\
\hline
\end{tabular}


- Model d:

$T O T_{2} I N V S_{i}=G R O W T H{ }_{-} S_{i}+P R O F I T_{-} S_{i}+R I S K_{-} S_{i}-$ $F L_{i}+$ FIRM $_{\text {Agei }}+$ FIRM $_{\text {Sizei }}+$ EDU $_{\text {Leveli }}+$ GENDER $_{i, t}+e_{i}$.

Beside analyzing behavioral and non-behavioral factors of SME's owner in making financial decisions, this study also employe a cluster analysis to group number of samples into several categories. It is intended to see a map of SME owners' behavior in Surakarta, Central Java.

\section{Result}

Based on the data collected from sample members, the first step carried out in this study was to cluster of 482 business owners based on the behavioral dimension. As mentioned above, it is useful to identify the characteristics of SME's owner behavior according to the behavioral dimension that was set at the beginning. Moreover, to employ it, this study uses cluster analysis to create a group of sample members. The results are as follows:

Table 3. The result of cluster analysis (source: developed in the current study)

\begin{tabular}{|l|l|l|l|l|l|}
\hline Statements & $\begin{array}{l}\text { Clus- } \\
\text { ter 1 }\end{array}$ & $\begin{array}{l}\text { Clus- } \\
\text { ter 2 }\end{array}$ & $\begin{array}{l}\text { Clus- } \\
\text { ter 3 }\end{array}$ & F stats & $p$-value \\
\hline $\begin{array}{l}\text { The main goal } \\
\text { of a business is } \\
\text { to increase and } \\
\text { expand market } \\
\text { share (opening } \\
\text { new branches) } \\
\text { as quickly as } \\
\text { possible. }\end{array}$ & 2.54 & 4.07 & 3.16 & 91.60 & 0.00 \\
\hline $\begin{array}{l}\text { The main goal of } \\
\text { business is to get } \\
\text { the maximum } \\
\text { profit as much as } \\
\text { possible. }\end{array}$ & 2.58 & 4.02 & 3.28 & 94.75 & 0.00 \\
\hline $\begin{array}{l}\text { I will maintain } \\
\text { my business } \\
\text { ownership with all } \\
\text { my strength (Will } \\
\text { not share business } \\
\text { ownership) }\end{array}$ & 1.83 & 4.01 & 3.71 & 302.39 & 0.00 \\
\hline $\begin{array}{l}\text { I dare to take } \\
\text { as much risk } \\
\text { as possible to } \\
\text { accelerate the pace } \\
\text { of growth of my } \\
\text { business. }\end{array}$ & 2.57 & 3.99 & 2.97 & 115.83 & 0.00 \\
\hline
\end{tabular}

According to Table 3, this research clustered the samples into three big clusters. The table showed that average treatment value of member in cluster 1 were growthseeking 2.54, profit-seeking 2.58, ownership-orientation 1.83 , and risk-seeking 2.57. Whereas cluster 2, pointed out growth-seeking 4.07, profit-seeking 3.28, ownership-orientation 4.01, and risk-seeking 3.99. Then Cluster 3 stated growth-seeking 3.16, profit-seeking 3.28, ownershiporientation 3.71, and risk-seeking 2.97. From this result

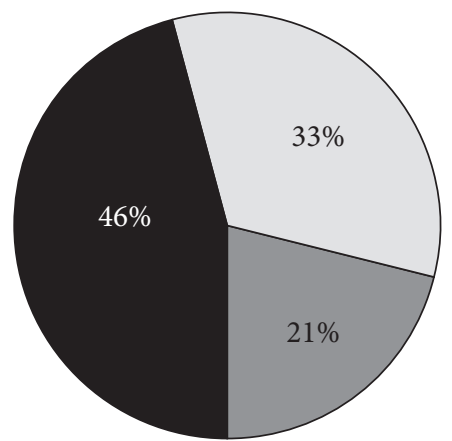

Risk Averse Player

Growth orientation Player

Steady Player

Figure 1. The distribution of SME's owners behavior

this study categorizes samples into three clusters based on their behavior. In which the explanation of each cluster as follows: Cluster 1 is a risk-averse player since its value of growth-seeking, risk-seeking, and profit-seeking is lower than the other clusters. Then, Cluster 2 is a growth player, a player who always chase or having orientation to business growth due to members of this cluster have higher value of growth-seeking, profit-seeking, and riskseeking than other clusters. While cluster 3 is categorized as a steady player, therein have the most moderate value compared to two earlier. In other words, cluster 3 could be interpreted as a player who is well established in making decisions and in running his business.

Figure 1 displayed the SMEs owners' profile in Surakarta, Central Java. Referring to the data, therein, $46 \%$ of SME's owners in Surakarta are steady players, 33\% riskaverse players, and $21 \%$ growth-orientation players. Besides of that, Figure 2 also shows the financing and investment behavior of each player.

Referring to Figure 2, risk-averse player has the lowest debt usage as well as the highest savings deposits compared to growth orientation player, and steady player. Furthermore, the result also proved that steady player as an established player, that was figured out from the high and more balanced cumulative value, both debt usage and total saving deposit than other players. Moreover, growthorientation players that always characterized as more likely risk and growth-seeking were so proved by Figure 2,

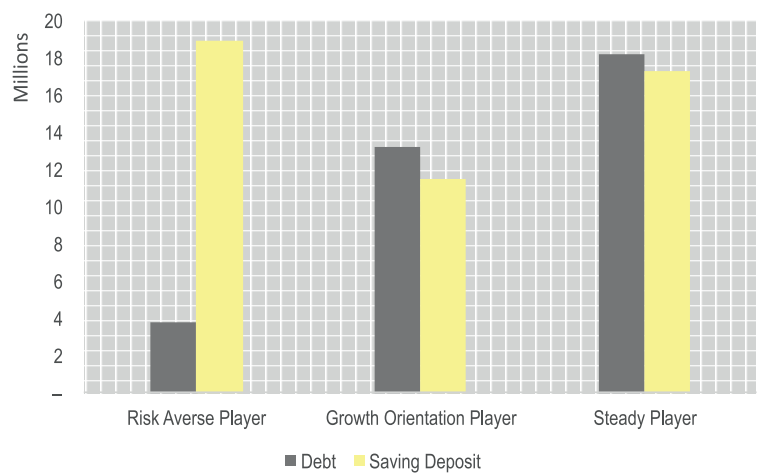

Figure 2. The distribution of SME's owners behavior 
that showed debt usage more than their saving deposits. The margin of both is around IDR 1.8 million, and this was roughly IDR 835 thousand greater than steady player had. Therefore, this confirmed the elucidation of growthorientation of the owners. Table 4 and Table 5 exhibited the results of HLMR and LR analysis on either financing decisions (models a and $\mathrm{b}$ ) and investment decisions (models $\mathrm{c}$ and $\mathrm{d}$ ) of SME's owners. As mentioned previously, this study employed a hierarchical linear multiple regression (HLMR) model to observe the weight of each independent variable on model's robustness.

Table 4, mainly, in the model (a) deduced that riskseeking, growth-seeking, and profit-seeking behaviours had a significant positive effect on SME's decision in debt usage. This evidence proved our hypothesis that higher risk-seeking behaviour would bring up likeliness of debt usage for a financing decision. So are regarding the two other behaviours, which are growth-seeking and profitseeking. Correspondingly, model (b) in Table 4 ascertained a positively significant impact of profit-seeking, growthseeking, and risk-seeking behaviours on the amount of debt held by SME owners. It underlined our hypothesis, which asserted that the higher of the value of those behaviours would affect the higher amount of debt usage.

The value of Nagelkerke $\mathrm{R}$ square settled the robustness of HLMR analysis, whereas adjusted $\mathrm{R}$ square implied the robustness of LR analysis. As derived in Table 4, this research revealed the incremental of both Nagelkerke $\mathrm{R}$ square as well the adjusted $\mathrm{R}$ square. Moreover, value of Nagelker R square of the model (1a) to model (6a) increased significantly from $2 \%$ to $26 \%$. It asserted the strength of independent variables is approximately $26 \%$ in verifying the variance of dependent variable. Similarly, another critical thing to remember is the result of robustness testing on LR analysis, therein incrementally rise to $15 \%$. It means that the strength of our model in estimating variance of total debt usage was approximately $15 \%$.

Table 5 unfolded the results of several factors affected SMEs owners' investment decisions. As described in the model (c), four independent variables have a significant effect on investment decisions, such as financial literacy, firm size, education level, and gender. Finally, the result habituated our hypothesis, which came out with a positive force of those variables on investment decisions. Considerably, it means that the higher level of financial literacy as well as the educational level, the more likely they decide to invest. Another critical thing to remember is the statistical model robustness of model (c). The variance of independent variables could enumerate $25 \%$ of dependent variable's variation.

Moreover, this research has discovered a shred of compelling evidence exhibited the negative effect of gender on investment decisions. Precisely, if the SME owners are men, they are less likely to save their funds in terms of FI's saving deposits. To put it another way, woman SMEs owners more likely interest in investing than men. Similarly, another key fact to remember, that model (d) in Table 5 invented the significant relation of financial literacy, firm size, educational level, and gender on the amount of debt usage by SME owners. Moreover, as stated earlier three variables have positive effect, whereas gender is negatively related to the amount of debt usage.

\section{Discussion}

The results of this study make an essential contribution to the headway of SME's issues, both theoretically and practically. Theoretically, this study offers evidences that

Table 4. The result of regression analysis on financing decision (using debt in FI)

\begin{tabular}{|c|c|c|c|c|c|c|c|c|c|c|c|c|}
\hline \multirow[b]{2}{*}{ IV } & \multicolumn{6}{|c|}{ External Financing Decision (Debt in FI) } & \multicolumn{6}{|c|}{ Total External Financing (Debt in FI) } \\
\hline & $\begin{array}{l}\text { Model } \\
\text { (1a) }\end{array}$ & $\begin{array}{l}\text { Model } \\
(2 \mathrm{a})\end{array}$ & $\begin{array}{l}\text { Model } \\
(3 a)\end{array}$ & $\begin{array}{l}\text { Model } \\
(4 a)\end{array}$ & $\begin{array}{l}\text { Model } \\
(5 a)\end{array}$ & $\begin{array}{l}\text { Model } \\
(6 a)\end{array}$ & $\begin{array}{l}\text { Model } \\
\text { (1b) }\end{array}$ & $\begin{array}{l}\text { Model } \\
(2 \mathrm{~b})\end{array}$ & $\begin{array}{l}\text { Model } \\
(3 \mathrm{~b})\end{array}$ & $\begin{array}{l}\text { Model } \\
\text { (4b) }\end{array}$ & $\begin{array}{l}\text { Model } \\
(5 b)\end{array}$ & $\begin{array}{l}\text { Model } \\
\text { (6b) }\end{array}$ \\
\hline Cons & $-2.98^{* * *}$ & $-4.81^{\star * *}$ & $-5.58^{\star * *}$ & $-5.73^{* * *}$ & $-5.90^{* * *}$ & $-5.81^{\star * *}$ & $-0.35^{\star * *}$ & $-0.95^{\star * \star}$ & $-1.15^{\star * *}$ & $-1.16^{\star * *}$ & $-1.29^{* * *}$ & $-2.36^{* * *}$ \\
\hline GROWTH_S & $0.76^{* * *}$ & $0.62^{* * *}$ & $0.52^{* * *}$ & $0.50^{* * *}$ & $0.48^{* * *}$ & $0.46^{* * *}$ & $0.29^{* * *}$ & $0.22^{* * *}$ & $0.17^{\star * \star}$ & $0.16^{* * *}$ & $0.17^{* * *}$ & $0.16^{* * *}$ \\
\hline PROFIT_S & & $0.66^{* * *}$ & $0.55^{\star * \star}$ & $0.51^{* * *}$ & $0.51^{\star * \star}$ & $0.52^{\star * *}$ & & $0.25^{\star * *}$ & $0.20^{* \star *}$ & $0.20^{* * *}$ & $0.20^{\star * \star}$ & $0.20^{\star \star \star}$ \\
\hline RISK_S & & & $0.45^{\star \star *}$ & $0.41^{\star * *}$ & $0.42^{\star * *}$ & $0.47^{\star * *}$ & & & $0.15^{\star * \star}$ & $0.15^{* * *}$ & $0.16^{\star \star *}$ & $0.17^{\star \star \star}$ \\
\hline CONTROL_S & & & & 0.16 & 0.14 & 0.11 & & & & $0.02^{* * *}$ & 0.01 & 0.02 \\
\hline FL & & & & & 0.06 & 0.04 & & & & & 0.04 & 0.03 \\
\hline Firm_Age & & & & & & -0.01 & & & & & & -0.02 \\
\hline Firm_Size & & & & & & -0.03 & & & & & & $0.1^{* *}$ \\
\hline Education_Level & & & & & & 0.18 & & & & & & 0.01 \\
\hline Gender & & & & & & -0.06 & & & & & & -0.07 \\
\hline Chi-Square & $33.6^{* * *}$ & $51.9^{* * *}$ & $59.35^{\star * *}$ & $60.40^{* * *}$ & $61.17^{\star \star \star}$ & $63.22^{\star * *}$ & & & & & & \\
\hline F-Statistic & & & & & & & $30.83^{* * *}$ & $24.61^{* * *}$ & $18.59^{* * *}$ & $13.92^{* * *}$ & $11.53^{\star * *}$ & $6.88^{\star * *}$ \\
\hline Nagelkerke $\mathrm{R}^{2}$ & 0.14 & 0.21 & 0.24 & 0.25 & 0.25 & 0.26 & & & & & & \\
\hline Adjusted $\mathrm{R}^{2}$ & & & & & & & 0.09 & 0.14 & 0.15 & 0.15 & 0.15 & 0.15 \\
\hline
\end{tabular}

Note: ${ }^{* *}$ significant at $5 \%,{ }^{* *}$ significant at $10 \%$, significant at $5 \%$. 
Table 5. The result of regression analysis on saving decision in FI

\begin{tabular}{|c|c|c|c|c|c|c|c|c|c|c|c|c|}
\hline \multirow[b]{2}{*}{ IV } & \multicolumn{6}{|c|}{ Deposit Decision (Saving in FI) } & \multicolumn{6}{|c|}{ Total Deposit (Saving in FI) } \\
\hline & $\begin{array}{l}\text { Model } \\
\text { (1c) }\end{array}$ & $\begin{array}{l}\text { Model } \\
(2 c)\end{array}$ & $\begin{array}{l}\text { Model } \\
(3 c)\end{array}$ & $\begin{array}{l}\text { Model } \\
(4 c)\end{array}$ & $\begin{array}{l}\text { Model } \\
(5 c)\end{array}$ & $\begin{array}{l}\text { Model } \\
\text { (6c) }\end{array}$ & $\begin{array}{l}\text { Model } \\
\text { (1d) }\end{array}$ & $\begin{array}{l}\text { Model } \\
(2 \mathrm{~d})\end{array}$ & $\begin{array}{l}\text { Model } \\
(3 \mathrm{~d})\end{array}$ & $\begin{array}{l}\text { Model } \\
(4 \mathrm{~d})\end{array}$ & $\begin{array}{l}\text { Model } \\
\text { (5d) }\end{array}$ & $\begin{array}{c}\text { Model } \\
\text { (6d) }\end{array}$ \\
\hline Cons & 0.17 & 0.45 & 0.43 & 0.36 & -0.38 & -9.12 & 0.67 & 0.68 & 0.67 & 0.68 & 0.50 & -0.90 \\
\hline GROWTH_S & 0.49 & 0.16 & 0.15 & 0.14 & 0.17 & 0.16 & 0.02 & 0.02 & 0.02 & 0.02 & 0.02 & 0.01 \\
\hline PROFIT_S & & 0.01 & 0.01 & 0.00 & -0.01 & -0.01 & & -0.00 & -0.01 & -0.00 & -0.00 & 0.00 \\
\hline RISK_S & & & 0.06 & 0.07 & 0.11 & 0.16 & & & 0.01 & 0.01 & 0.03 & 0.04 \\
\hline CONTROL_S & & & & 0.00 & -0.03 & -0.04 & & & & -0.00 & -0.01 & -0.01 \\
\hline FL & & & & & $0.27^{\star * *}$ & $0.24^{* * *}$ & & & & & $0.05^{\star \star \star}$ & $0.04^{* * *}$ \\
\hline Firm_Age & & & & & & 0.01 & & & & & & -0.00 \\
\hline Firm_Size & & & & & & $0.62^{* * * *}$ & & & & & & $0.10^{* * *}$ \\
\hline Education_Level & & & & & & $0.46^{* * *}$ & & & & & & $0.05^{* * *}$ \\
\hline Gender & & & & & & $-0.68^{\star * *}$ & & & & & & $-0.11^{* * *}$ \\
\hline Chi-Square & 0.16 & 0.38 & 0.58 & 2.01 & $16.10^{* * *}$ & $59.51^{\star * *}$ & & & & & & \\
\hline F-Statistic & & & & & & & 0.59 & 0.30 & 0.23 & 0.18 & $3.15^{\star * *}$ & $6.29^{* * *}$ \\
\hline Nagelkerke $\mathrm{R}^{2}$ & 0.01 & 0.01 & 0.01 & 0.01 & 0.07 & 0.24 & & & & & & \\
\hline Adjusted $\mathrm{R}^{2}$ & & & & & & & 0.00 & 0.00 & 0.00 & 0.00 & 0.05 & 0.16 \\
\hline
\end{tabular}

Note: ${ }^{* *}$ significant at $5 \%,{ }^{* *}$ significant at $10 \%$, significant at $5 \%$.

SME owners' behaviors are essential factor that affect their financing decisions. This result suggests an alternative approach to discover the theory of financing decisions. In the context of investment decisions, this study discovers that the predictors of SME owners' investment decisions are non-behavioral factors, such as level of education and financial literacy. Indeed, both have significant in terms of praxis such as optimizing the credit portfolio, and FIs should design their content marketing close to those behaviors, which in this study have significant influence on financing decisions. Whereas, as optimizing sales of investment products, FIs should design their sales promotions for investment products, such as savings deposits, by providing educational content to potential customers. That way, this could increase knowledge of potential customers, as well carry an impact to prospective consumers to more likely exploit FIs investment products.

This study also conducts a cluster analysis aim to classify the characteristics of SME owners based on their behavioral dimensions. As a result, this study discovers three clusters of SME owners' behavioral profiles (behavioural mapping) in Surakarta, such as risk-averse players, growth orientation players, and steady players. Each of these players has different dimensions of behavioral characteristics and financial decision. For instance, risk-averse players have the highest tolerance profile for risk as well less debt usage compare to other clusters. This evidence becomes imperative for government to formulate policies that relates to the development of SMEs industry. For instance, the Indonesian government and FIs have been working together to extend credit to SME industry through scheme of Kredit Usaha Rakyat (KUR). Based on the data from Coordinating Ministry for Economic Affairs of Indonesia, the realization of KUR in 2020 was 15.80 trillions. However, the program has not providing an optimal impact since it has not evenly distributed as illustrated by Figure 2, that the distribution of debt use was uneven in each SME cluster in Surakarta. Such inequality issue of KUR distribution can be reduced through SME behavioral mapping that found in this study. KUR scheme should be formulated and designed strategically by looking carefully on the cynosure of SME owoners behaviour. Government as executive policy maker on preserved SME industry could prompt a fresh scheme of financing products based on SME's behavioral mapping appropriately. Indeed, it is extremely critical as the contribution of SME industry toward gross domestic product of Indonesia was $61.07 \%$ in 2020.

As mentioned earlier, the results of this study can also inspire further studies, especially relates to the development of financial decision theory discourse in SMEs industry. Because the behavioral dimensions are numerous, subsequent researchers should further elaborate, especially behavioral factors that have potential impact to influence SMEs owners financial decisions. Likewise, non-behavioral factors such as SMEs owners knowledge which has the potential to influence investment decisions. The next researcher should elaborate deeply on the proxy of SME owner knowledge.

\section{Conclusions}

This study seeks to examine SMEs owners' behavioral and non-behavioral factors in financing and investment. The behavioral factors introduced in this study are riskseeking, growth-seeking, profit-seeking, and ownershiporientation, as well the non-behavioral factors, which are firm age and firm size. In contrast to previous studies, primary constraints found in this study is the inadequate knowledge of ownership by SMEs owners themselves. 
Therefore, this study introduced educational level and financial literacy as a proxy of SME owners' knowledge on affecting SME's financial decisions. Besides verifying the determinant of SME's financial decisions. This research also conducted a cluster analysis to classified SME's owners in Surakarta. It aimed to form a behavioural cluster mapping of SME's industry.

As for the results, based on cluster analysis, this study divided the sample into three clusters. Then, every cluster is analyzed based on four behaviors that utilized in this study. The three significant clusters are categorized based on characteristics of behavioral value they had. Three significant clusters are given the following attributes as a riskaverse player, growth player, and steady player. In other words, instead of being a single characteristic, SME industry in Surakarta had been compounding. It has significant implications because the policies applied in every cluster should employed a different approach.

Furthermore, this study found that risk-seeking, growth-seeking, and profit-seeking have a positive and significant effect on decision to use and amount of debt owned. As for investment decisions, behavioral variables did not have significant effect. Conversely, financial literacy, firm size, and educational level have positive and significant effect on decisions to save and amount saving deposits in FIs. Based on the results of these tests, a conclusion can be drawn that behavioral aspect has a more significant influence on decision to use and amount of debt owned SMEs owners. In contrast, non-behavioral had more influence than behavioural aspect on decisions to save and amount of saving deposits in FIs. This means that irrationality that had been driven by behavioral aspects is more influential on decision to use and amount of debt rather than on investment decisions. In which the adequacy of knowledge that had been understood as a driver of rationality influence more on investment decisions (i.e decision to save and amount of saving deposits). It is considerably fascinating evidences, both its contribution to theoretical and practical development in the realm of financial decisions.

\section{References}

Alali, F., \& Romero, S. (2013). Characteristics of failed U.S. commercial banks: An exploratory study. Accounting and Finance, 53(4), 1149-1174.

https://doi.org/10.1111/j.1467-629X.2012.00491.x

Aren, S., \& Zengin, A. N. (2016). Influence of financial literacy and risk perception on choice of investment. Procedia - Social and Behavioral Sciences, 235, 656-663.

https://doi.org/10.1016/j.sbspro.2016.11.047

Arend, R. J. (2014). Entrepreneurship and dynamic capabilities: How firm age and size affect the "capability enhancementSME performance" relationship. Small Business Economics, 42(1), 33-57. https://doi.org/10.1007/s11187-012-9461-9

Arya, S., Eckel, C., \& Wichman, C. (2013). Anatomy of the credit score. Journal of Economic Behavior and Organization, 95, 175-185. https://doi.org/10.1016/j.jebo.2011.05.005

Awaluddin, M. (2015). Digital entrepreneurshift. PT Gramedia Pustaka Utama Jakarta.
Baker, H. K., Kumar, S., \& Rao, P. (2020). Financing preferences and practices of Indian SMEs. Global Finance Journal, 43, 100388. https://doi.org/10.1016/j.gf.2017.10.003

Bannier, C. E., \& Schwarz, M. (2018). Gender- and educationrelated effects of financial literacy and confidence on financial wealth. Journal of Economic Psychology, 67, 66-86. https://doi.org/10.1016/j.joep.2018.05.005

Botta, M. (2019). Financing decisions and performance of Italian SMEs in the hotel industry. Cornell Hospitality Quarterly, 60(4), 335-354. https://doi.org/10.1177/1938965518816948

Cassar, G., \& Holmes, S. (2003). Capital structure and financing of SMEs: Australian evidence. Accounting, 43(2), 123-147. https://doi.org/10.1111/1467-629X.t01-1-00085

Chijoriga, M. M. (2011). Application of multiple discriminant analysis (MDA) as a credit scoring and risk assessment model. International Journal of Emerging Markets, 6(2), 132-147. https://doi.org/10.1108/17468801111119498

Dong, Y., \& Men, C. (2014). SME financing in emerging markets: Firm characteristics, banking structure and institutions. Emerging Markets Finance and Trade, 50(1), 120-149. https://doi.org/10.2753/REE1540-496X500107

Eckel, C. C., Johnson, C., Montmarquette, C., \& Rojas, C. (2007). Debt aversion and the demand for loans for postsecondary education. Public Finance Review, 35(2), 233-262. https://doi.org/10.1177/1091142106292774

Ferrando, A., Popov, A., \& Udell, G. F. (2017). Sovereign stress and SMEs' access to finance: Evidence from the ECB's SAFE survey. Journal of Banking and Finance, 81, 65-80. https://doi.org/10.1016/j.jbankfin.2017.04.012

Fujiki, H. (2020). Cash demand and financial literacy: A case study using Japanese survey data. Japan and the World Economy, 54, 100998. https://doi.org/10.1016/j.japwor.2020.100998

Galli, E., Mascia, D. V., \& Rossi, S. P. S. (2019). Bank credit constraints for women-led SMEs: Self-restraint or lender bias? European Financial Management, 26(4), 1147-1188. https://doi.org/10.1111/eufm.12255

García-Teruel, P. J., \& Martínez-Solano, P. (2010). Determinants of trade credit: A comparative study of European SMEs. International Small Business Journal, 28(3), 215-233. https://doi.org/10.1177/0266242609360603

Ghafoorifard, M., Sheykh, B., Shakibaee, M., \& Joshaghan, N. S. (2014). Assessing the relationship between firm size, age and financial performance in listed companies on Tehran stock exchange. International Journal of Scientific Management \& Development, 2(11), 631-635. https://search.ebscohost.com/ login. aspx ?direct $=$ true $\& d b=b t h \& A N=99978926 \&$ site $=$ eho st-live

Grohmann, A. (2018). Financial literacy and financial behavior: Evidence from the emerging Asian middle class. Pacific-Basin Finance Journal, 48, 129-143. https://doi.org/10.1016/j.pacfin.2018.01.007

Gupta, J., \& Gregoriou, A. (2018). Impact of market-based finance on SMEs failure. Economic Modelling, 69, 13-25. https://doi.org/10.1016/j.econmod.2017.09.004

Iturralde, T., Maseda, A., \& San-Jose, L. (2010). Empirical evidence of banking relationships for Spanish SMEs. International Small Business Journal, 28(3), 274-295. https://doi.org/10.1177/0266242609360706

Jappelli, T., \& Padula, M. (2013). Investment in financial literacy and saving decisions. Journal of Banking and Finance, 37(8), 2779-2792. https://doi.org/10.1016/j.jbankfin.2013.03.019

Jiang, J., Liao, L., Wang, Z., \& Xiang, H. (2020). Financial literacy and retail investors' financial welfare: Evidence from mutual 
fund investment outcomes in China. Pacific Basin Finance Journal, 59, 101242.

https://doi.org/10.1016/j.pacfin.2019.101242

Karpavičius, S., \& Yu, F. (2019). Managerial risk incentives and a firm's financing policy. Journal of Banking and Finance, 100, 167-181. https://doi.org/10.1016/j.jbankfin.2019.01.013

Kon, Y., \& Storey, D. J. (2003). A theory of discouraged borrowers. Small Business Economics, 21(1), 37-49. https://doi.org/10.1023/A:1024447603600

Ling, Y., Zhao, H., \& Baron, R. A. (2007). Influence of founder CEOs' personal values on firm performance: Moderating effects of firm age and size. Journal of Management, 33(5), 673-696. https://doi.org/10.1177/0149206307305564

LiPuma, J. A., Newbert, S. L., \& Doh, J. P. (2013). The effect of institutional quality on firm export performance in emerging economies: A contingency model of firm age and size. Small Business Economics, 40, 817-841. https://doi.org/10.1007/s11187-011-9395-7

Loderer, C. F., \& Waelchli, U. (2011). Firm age and performance. SSRN Electronic Journal. https://doi.org/10.2139/ssrn.1342248

Lusardi, A., Michaud, P., \& Mitchell, O. S. (2019). Assessing the impact of financial education programs: A quantitative model. Economics of Education Review, 78, 101899. https://doi.org/10.1016/j.econedurev.2019.05.006

Maes, E., Dewaelheyns, N., Fuss, C., \& Van Hulle, C. (2019). The impact of exporting on financial debt choices of SMEs. Journal of Business Research, 102, 56-73. https://doi.org/10.1016/j.jbusres.2019.05.008

McCarthy, S., Oliver, B., \& Verreynne, M. L. (2017). Bank financing and credit rationing of Australian SMEs. Australian Journal of Management, 42(1), 58-85. https://doi.org/10.1177/0312896215587316

Mouna, A., \& Anis, J. (2017). Financial literacy in Tunisia: Its determinants and its implications on investment behavior. Research in International Business and Finance, 39, 568-577. https://doi.org/10.1016/j.ribaf.2016.09.018

Mulyani, E., Singh, H., \& Mishra, S. (2016). Dividends, leverage, and family ownership in the emerging Indonesian market. Journal of International Financial Markets, Institutions and Money, 43, 16-29. https://doi.org/10.1016/j.intfin.2016.03.004

Myers, S. C., \& Majluf, N. S. (1984). Corporate financing and investment decisions when firms have information that investors do not have*. Journal of Financial Economics, 13(2), 187-221. https://doi.org/10.1016/0304-405X(84)90023-0

Netle, J. P. C., \& Munger, M. C. (2016). The "Character" of profit and loss. In Questions of character. Oxford University Press. https://doi.org/10.1093/acprof:oso/9780199357703.003.0020

Nizaeva, M., \& Coskun, A. (2019). Investigating the relationship between financial constraint and growth of SMEs in South Eastern Europe. SAGE Open, 9(3).

https://doi.org/10.1177/2158244019876269

OECD. (2011). Measuring financial literacy: Questionnaire and guidance notes for conducting an internationally comparable survey of financial literacy. Organisation for Economic Cooperation and Development. https://www.oecd.org/finance/ financial-education/49319977.pdf

Osei-Assibey, E., \& Asenso, J. K. (2015). Regulatory capital and its effect on credit growth, non-performing loans and bank efficiency: Evidence from Ghana. Journal of Financial Economic Policy, 7(4), 401-420.

https://doi.org/10.1108/JFEP-03-2015-0018
Raharja, B. S. (2012). Fenomena underpricing dan kinerja jangka panjang pada saat IPO: pengujian informasi asimetri. Universitas Gadjah Mada.

Raharja, B. S. (2014). Underpricing Pada Saat IPO: Pengujian Teori Asimetri Informasi. Jurnal Analisis Bisnis Dan Ekonomi, 12(2).

Raharja, B. S., \& Mranani, M. (2019). The nonlinear effect of debt on firm performance: The evidence from Indonesia [Kesan tidak linear hutang terhadap prestasi firma: Bukti daripada Indonesia]. Jurnal Ekonomi Malaysia, 53(3). https://doi.org/10.17576/JEM-2019-5303-1

Raharja, B. S., Suhaeli, D., \& Mranani, M. (2017). Did manager behave overconfidently? Financial Studies, 21(3).

Ramezani, C. A., Soenen, L., \& Jung, A. (2002). Growth, corporate profitability, and value creation. Financial Analysts Journal, 58(6), 56-67. https://doi.org/10.2469/faj.v58.n6.2486

Rao, P., \& Kumar, S. (2018). Reflection of owner's attributes in financing decisions of SMEs. Small Enterprise Research, 25(1), 52-68. https://doi.org/10.1080/13215906.2018.1428908

Rao, P., Kumar, S., \& Madhavan, V. (2019). A study on factors driving the capital structure decisions of Small and Medium Enterprises (SMEs) in India. IIMB Management Review, 31(1), 37-50. https://doi.org/10.1016/j.iimb.2018.08.010

Rooij, M. Van, Lusardi, A., \& Alessie, R. (2011). Financial literacy and stock market participation. Journal of Financial Economics, 101(2), 449-472. https://doi.org/10.1016/j.jfineco.2011.03.006

Setyawan Agus, A., Isa, M., Wajdi, W. F. M., Syamsudin, \& Nugroho Permono, S. (2015). An assessment of SME competitiveness in Indonesia. Journal of Competitiveness, 7(2), 60-74. https://doi.org/10.7441/joc.2015.02.04

Shleifer, A., \& Vishny, R. W. (1986). Large shareholders and corporate control. Journal of Political Economy, 94(3), 461-488. https://doi.org/10.1086/261385

Situm, M. (2014). The age and size of the firm as relevant predictors for bankruptcy. Journal of Applied Economics and Business, 2(1), 5-30.

Sun, H., Yuen, D. C. Y., Zhang, J., \& Zhang, X. (2020). Is knowledge powerful? Evidence from financial education and earnings quality. Research in International Business and Finance, 52, 101179. https://doi.org/10.1016/j.ribaf.2019.101179

Tambunan, T. (2009). Export-oriented small and medium industry clusters in Indonesia. Journal of Enterprising Communities, 3(1), 25-58. https://doi.org/10.1108/17506200910943661

Vithessonthi, C. (2016). Deflation, bank credit growth, and nonperforming loans: Evidence from Japan. International Review of Financial Analysis, 45, 295-305. https://doi.org/10.1016/j.irfa.2016.04.003

Waharini, F. M., Raharja, B. S., \& Kurnia, M. (2018). Pendampingan Sistem Pelaporan Keuangan Pada Badan Usaha Milik Desa (BUMDes) Karya Manunggal. Community Empowerment, 3(2), 45-48. https://doi.org/10.31603/ce.v3i2.2452

Zhang, Y., Jia, Q., Chen, C., \& Yin, Z. (2020). Risk attitude, financial literacy and household consumption: Evidence from stock market crash in China. Economic Modelling, 94, 995-1006. https://doi.org/10.1016/j.econmod.2020.02.040 